\title{
Studies on the Haemagglutinin Present in Coxsackie A 7 Virus-Infected Suckling Mouse Tissue
}

\author{
By J. D. WILLIAMSON* AND N. R. GRIST \\ Viral Epidemiology Unit of the University of Glasgow, \\ Ruchill Hospital, Glasgow, Scotland
}

(Received 22 July 1965)

\begin{abstract}
SUMMARY
Absorption and centrifugation studies established that the haemagglutinin specifically associated with suckling mouse tissue infected with Coxsackie A 7 virus is particulate but distinct from the infectious particle. The haemagglutinin resembles other enteroviral haemagglutinins in being inactivated by $p$-chloromercuribenzoic acid. This property, together with other physical and chemical properties, suggests that the haemagglutinin is a protein. There is a serological relationship between the haemagglutinin and other non-haemagglutinating, serologically reactive substances present in tissues infected with Coxsackie A7 virus.
\end{abstract}

\section{IN'TRODUCTION}

Coxsackie A 7 virus is outstanding among enteroviruses other than polioviruses as a cause of paralytic disease of man (Voroshilova, 1964; Rossi, Vassella \& Rentsch, 1964; Grist \& Bell, 1964). The virus resembles poliovirus in pathogenicity for man and monkey and shares with type 2 poliovirus a limited pathogenicity for adult rodents (Chumakov et al. 1956; Habel \& Loomis, 1957; Grist \& Roberts, 1962; Chlap \& Lutynski, 1964). However, the Coxsackie virus is antigenically distinct from poliovirus and is pathogenic for day-old suckling mice, causing myositis characteristic of group A Coxsackie virus infection (Habel \& Loomis, 1957; Voroshilova \& Chumakov, 1959).

A strain of Coxsackie A7 virus was isolated during a study of an outbreak of poliomyelitis-like illness in Scotland in 1959 (Grist, 1960). Extracts of tissues from day-old suckling mice infected with the virus strain agglutinated vaccinia-agglutinable fowl red cells. Human, mouse and vaccinia-inagglutinable fowl red cells were not agglutinated. Haemagglutinins were not detected in similarly prepared extracts of uninfected suckling mouse tissue nor in those infected with other prototype group A Coxsackie strains (Grist, 1962). Haemagglutination was specifically inhibited by homologous antiserum. From these observations it appeared that the haemagglutinins detected were specifically associated with suckling mouse tissue infected with Coxsackie A 7 virus.

The present paper reports an investigation of the relationship of the haemagglutinin to the infective particle and a comparison of the properties of the haemagglutinin with those of previously described viral haemagglutinins.

\footnotetext{
* Present address : Department of Virology, St Mary's Hospital Medical School, London, W. 2.
} 


\section{METHODS}

Virus. The virus used in this study was the 1034 strain isolated in 1959 from a paralysed child (Grist, 1960). This strain reacted as a type A7 strain related to both Dalldorf's prototype and the Russian AB-IV strain.

Preparation of infected tissue extracts. Day-old suckling mice were injected intraperitoneally with a dose of virus calculated to produce paralysis 4-5 days after injection. The carcasses were dissected to leave mainly skeletal muscle which was then homogenized with phosphate-buffered saline to give a $20 \%(\mathrm{w} / \mathrm{v})$ suspension. Extracts were cleared by centrifugation and stored at $-20^{\circ}$ until used. Before use, the extracts were thawed and centrifuged again to remove a flocculum, leaving a clear, straw-coloured supernatant fluid.

Haemagglutination tests. As a result of experiments to be described (see Results) the following procedure was adopted for routine haemagglutination tests. Blood from fowls with vaccinia-agglutinable red blood cells (r.b.c.) was collected aseptically by cardiac puncture into Alsever's solution. The r.b.c. were washed with physiological saline and used as a $\mathbf{0 . 5} \%$ suspension in saline. Cells not used immediately were stored in Alsever's solution at $4^{\circ}$ until they showed signs of instability. Haemagglutination tests were carried out in plastic plates by addition of $0.3 \mathrm{ml} .0 .5 \%$ r.b.c. to $0.3 \mathrm{ml}$. of twofold dilutions of $20 \%$ suckling mouse carcass suspensions in saline. End-points are expressed as reciprocals of the highest dilutions giving $3+$ to $4+$ haemagglutination by pattern formation.

Haemagglutination inhibition tests. One $100 \%$ haemagglutinin unit (final dilution of haemagglutinin giving $4+$ haemagglutination pattern) was added in $\mathbf{0 . 3} \mathbf{~ m l}$. amounts to $0.3 \mathrm{ml}$. of twofold dilutions of immune serum and the mixtures held at room temperature for $1 \mathrm{hr}$. After this period, $0.3 \mathrm{ml}$. of $0.5 \%$ r.b.c. was added to each mixture and to the appropriate controls. Results were read when r.b.c. had completely settled and are expressed as reciprocals of the highest dilution of immune serum giving complete inhibition of haemagglutination.

Complement-fixation tests. The method employed was the standard small-volume, cold-overnight technique of this laboratory (Grist $e t$ al. 1965). In brief, tests were performed in plastic plates using $0.1 \mathrm{ml}$. amounts of each reagent consisting of serial twofold dilutions of antigen, 4 units of antiserum (determined by chess-board titration) and 4 units of complement. After overnight fixation at $4^{\circ}$, plates were incubated at $37^{\circ}$ for $20 \mathrm{~min}$. and $0.1 \mathrm{ml}$. of $2 \%$ sensitized sheep cells added. Lysis was allowed to proceed at $37^{\circ}$ for $40 \mathrm{~min}$. and the plates then kept at $4^{\circ}$ until cells had settled. End-points are expressed as the reciprocal of the highest dilution of antigen giving complete or nearly complete fixation of complement.

Infectivity titrations. Serial tenfold dilutions of infective preparations were injected in $0.03 \mathrm{ml}$. amounts intraperitoneally into day-old suckling mice. A litter of at least seven animals was used for each dilution. The mice were observed for a total of 14 days for signs of paralysis; mice dying within $24 \mathrm{hr}$ of injection were rejected from the titration. The effective dose at which $50 \%$ of the animals injected showed paralysis (ED 50) was determined by the Kärber formula. Infectivity titres are expressed as the log. of the reciprocal of the ED 50 end-point $\left(\log _{10}\right.$ ED 50/ $0.03 \mathrm{ml}$.).

Neutralization tests. Serial twofold dilutions of immune serum were mixed with an 
equal volume of virus preparation containing $100 \mathrm{ED} 50 / 0.03 \mathrm{ml}$. and held at room temperature for $2 \mathrm{hr}$. The virus serum mixtures were then injected in $0.03 \mathrm{ml}$. amounts intraperitoneally into day-old suckling mice using a litter of at least seven animals for each dilution. Serum neutralization titres are expressed as reciprocals of $\mathbf{5 0} \%$ end-points determined by the Kärber formula.

Preparation of antiserum. Adult mice were immunized by four intraperitoneal injections at weekly intervals of $0.5 \mathrm{ml}$. amounts of $20 \%$ suspensions of carcasses from suckling mice infected with the 1034 strain. Seven days after the fourth injection, immunized mice were injected intraperitoneally with $0.2 \mathrm{ml}$. Landschütz ascites tumour fluid and the resultant immune ascitic fluid harvested 7 days later. Immune ascitic fluid was used for routine complement-fixation tests. Serum absorption experiments were carried out using immune serum obtained from immunized adult mice by cardiac puncture.

\section{RESULTS}

\section{Optimal conditions for demonstration of haemagglutination}

Salt. Extracts of infected tissue were dialysed against distilled water overnight and haemagglutination titres determined using various isotonic salt solutions as diluent and for preparation of $0.5 \%$ r.b.c. suspensions. Haemagglutination was not detectable when haemagglutination tests were carried out in isotonic solutions of glucose. Identical haemagglutination titres were obtained in isotonic solutions of $\mathrm{NaCl}, \mathrm{MgCl}_{2}, \mathrm{CaCl}_{2}$ and $\mathrm{Na}_{2} \mathrm{SO}_{4}$.

Haemagglutination by extracts of Coxsackie A7 virus-infected tissues is dependent, therefore, on the presence of salts. Since identical haemagglutination titres were obtained in media containing either only monovalent anions or cations or only divalent anions or cations, the valency of the salts in the medium was not critical.

Temperature. Haemagglutination titres up to 256 were obtained when tests were made at room temperature $\left(15-18^{\circ}\right)$ and parallel tests showed a twofold decrease at $4^{\circ}$ and a twofold increase at $37^{\circ}$ compared with titres obtained at room temperatures. The pattern of agglutinated cells remained stable for $24 \mathrm{hr}$ at each temperature.

Freshly prepared extracts of infected tissues, however, caused considerable haemolysis after prolonged incubation. Haemolysis was also demonstrable with vaccinia-inagglutinable r.b.c. and lysins were found in similarly prepared extracts of uninfected suckling mouse tissue. Haemolysis of vaccinia-agglutinable r.b.c. by extracts of infected tissue was not inhibited by 1034-immune serum. Thus haemolysis is not specifically associated with Coxsackie A7 virus-infected tissue but is due to lysins known to be present in homogenates of normal mouse tissue (Herberman, 1964).

$p H$. Haemagglutination titres were determined using diluents of different $\mathrm{pH}$ compatible with the stability of both the haemagglutinin and fowl r.b.c. Experiments were made at room temperature using physiological saline buffered with citrate buffer, pH 4.5-6.0, phosphate buffer, $\mathrm{pH} 7 \cdot 0-8 \cdot 0$, and glycine buffer, $\mathrm{pH} 9 \cdot 0$ $10 \cdot 5$.

Maximal haemagglutination titres were obtained between $\mathrm{pH} 4.5$ and $\mathrm{pH} 8.0$ but without a well-defined $\mathrm{pH}$ optimum. Increased alkalinity produced a progressive decrease in haemagglutination titre with a 32 -fold decrease in titre at $\mathrm{pH} 11.0 \mathrm{com}$ pared with the maximal titres. As a result of these experiments, haemagglutination 
tests were routinely carried out at room temperature as described in Methods. The $\mathrm{pH}$ of physiological saline used as a diluent was between $6 \cdot 4$ and $6 \cdot 8$.

\section{Relationship of the haemagglutinin to the infective particle}

Absorption studies. Extracts of tissue infected with Coxsackie A7 virus were absorbed at room temperature for $2 \mathrm{hr}$ with $5 \%$ suspensions of vaccinia-agglutinable and vaccinia-inagglutinable fowl r.b.c. The mixtures were kept at $4^{\circ}$ overnight and the supernatant fluids removed after deposition of the r.b.c. by centrifugation. The deposited cells were washed with saline at $4^{\circ}$, resuspended in saline to volumes equivalent to the original absorption mixtures and disrupted by two cycles of freezing and thawing. Supernatant fluids and suspensions of disrupted cells were assayed for infectivity, haemagglutinating and complement-fixing activity.

Table 1. Absorption of Coxsackie $A 7$ virus-infected suckling mouse tissue extract with vaccinia-agglutinable and vaccinia-inagglutinable fowl r.b.c.

Expt.
no.
1
2
3
4
5

Preparation

Unabsorbed extract

Absorbed with vaccinia-agglutinable fowl r.b.c.

Absorbed with vaccinia-inagglutinable fowl r.b.c.

Lysate of vaccinia-agglutinable fowl r.b.c. from Expt. 2

Lysate of vaccinia-inagglutinable fowl r.b.c. from Expt. 3

\begin{tabular}{|c|c|c|}
\hline \multicolumn{3}{|c|}{ Titres* } \\
\hline HA & CF & INF \\
\hline 128 & 64 & 6.9 \\
\hline 0 & 64 & $6 \cdot 8$ \\
\hline 128 & 64 & 6.8 \\
\hline- & 0 & $\mathbf{2 \cdot 0}$ \\
\hline - & 0 & 1.9 \\
\hline
\end{tabular}

* HA, haemagglutination; CF, complement fixation; INF, infectivity $=\log _{10}$ ED 50/0.03 ml.

Haemagglutinins were removed specifically from the infective extracts by absorption with vaccinia-agglutinable fowl r.b.c. (Table 1). Loss of haemagglutinating activity was not accompanied by any detectable decrease in infectivity titre. Owing to the lack of precision of the method used for infectivity titration this result does not exclude the possibility that haemagglutinating activity is associated with a small proportion of the total population of infective particles. However, such an association should have been revealed by a higher infectivity titre in the lysate of vaccinia-agglutinable fowl r.b.c. compared with that of vaccinia-inagglutinable fowl r.b.c. No such difference was detected. These results strongly suggest, therefore, that the haemagglutinin and infective particle are distinct entities.

In addition, there was no detectable decrease in complement-fixing activity of the infected tissue extracts compared with that of controls after complete removal of the haemagglutinins. Within the limits of sensitivity of the serological test, therefore, the haemagglutinin does not appear to be associated with complement-fixing activity.

Centrifugation studies. In order to investigate further the relationship of the haemagglutinin to the infective particle, extracts of tissues infected with Coxsackie A7 virus were examined by centrifugation. A saline extract of infected tissue was centrifuged repeatedly for constant periods of one hour at $4^{\circ}$ at increasing centrifugal force in the no. 40 rotor of a Spinco Model $L$ ultracentrifuge. After each period of centrifugation, samples were removed from the centre of the centrifuge tube. The infectivity, haemagglutinating and complement-fixing titres of each successive sample were determined (Fig. 1). 
The rate of sedimentation of haemagglutinating activity under the conditions described is thus greater than that of infectivity, confirming the conclusion drawn from the absorption experiments that the haemagglutinin and infective particle are distinct entities. Further, these studies show that the haemagglutinin is particulate and not a 'soluble substance'. Both the haemagglutinin and infective particle were found at the same level in equilibrium density gradient centrifugation experiments in caesium chloride (Grist, unpublished results). These experiments suggest that the haemagglutinin is a larger particle than the infective particle.

(a)

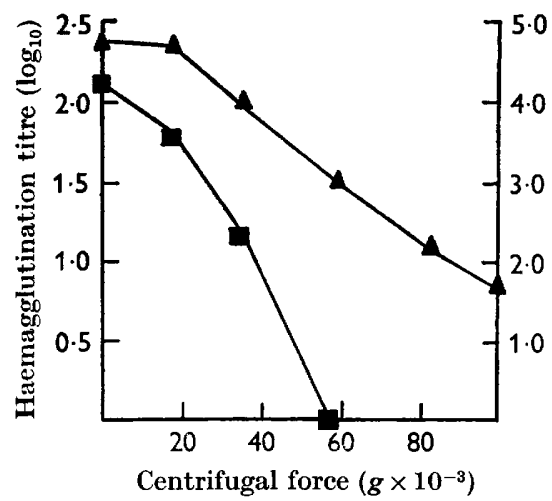

(b)

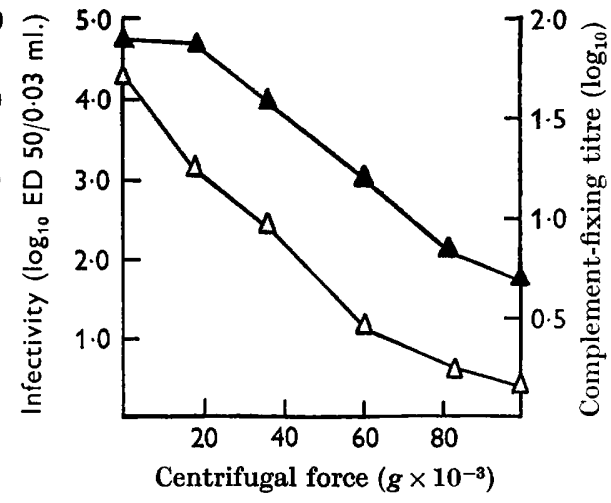

Fig. 1. Relative rates of sedimentation of infectivity, haemagglutinating and complement-fixing activities associated with extracts of Coxsackie A7 virus-infected suckling mouse tissue. (a) $\mathbf{\Delta}-\mathbf{\Delta}=$ infectivity; $\mathbf{-}=$ = haemagglutinating activity. (b) $\Delta-\Delta=$ infectivity, $\triangle-\triangle=$ complement-fixing activity.

Unlike haemagglutinating activity, the rate of sedimentation of complementfixing activity closely paralleled that of infectivity apart from the initial stages. Complement-fixing activity is mainly associated, therefore, with the infective particle. It is not possible to draw firm conclusions from the initial rate of sedimentation of complement-fixing activity which might suggest that this activity is independent of the infective particle.

\section{Effect of physical and chemical agents on the Coxsackie $A 7$ haemagglutinin}

Stability of the Coxsackie A7 haemagglutinin was tested under experimental conditions described in a systematic study of virus haemagglutinins by Buckland \& Tyrrell (1963). The results provide information relevant to the probable chemical nature of the haemagglutinin and its relationship to previously described virus haemagglutinins.

Coxsackie A7 haemagglutinin was completely stable over a range from $\mathrm{pH} 2$ to 10. Although Coxsackie viruses were not examined by Buckland \& Tyrrell, it is perhaps significant that those enteroviruses studied were found to be stable over a similar $\mathrm{pH}$ range. Haemagglutinating activity was lost after heating at $56^{\circ}$ for $60 \mathrm{~min}$. and after exposure to $4 \mathrm{M}$-urea or $0.005 \mathrm{M}$ - $p$-chloromercuribenzoic acid. Inactivation by $p$-chloromercuribenzoic acid was reversible by subsequent treatment of the inactivated haemagglutinin with $0.5 \mathrm{M}$-cysteine or glutathione at $37^{\circ}$ for $30 \mathrm{~min}$. These results, together with the precipitation of haemagglutinating activity 
by $25 \%$ ammonium sulphate, are compatible with a proteinaceous haemagglutinin. However, haemagglutinating activity was not affected by treatment with $1 \%$ papain, $0.01 \% \alpha$-chymotrypsin or $0.01 \%$ trypsin. Treatment with papain for longer periods or with $0.1 \%$ solutions of the two other enzymes at $37^{\circ}$ for $4 \mathrm{hr}$ resulted in a consistent twofold increase in haemagglutination titre. An increase in haemagglutination titre was also described following treatment of vaccinia-infected tissues with trypsin (Briody, 1951; Youngner \& Rubinstein, 1962).

Evidence against the association of haemagglutinating activity with either carbohydrate or lipid is provided by resistance to $0.046 \mathrm{M}$-potassium periodate and organic solvents in which the haemagglutinin is also insoluble. Nor was there detectable decrease in haemagglutinating titre after incubation at $37^{\circ}$ for up to $48 \mathrm{hr}$ with cobra venom. When examined under similar conditions, vaccinia haemagglutinin, prepared from vaccinia-infected chick embryo chorioallantoic membrane, was almost completely inactivated. Inactivation of vaccinia haemagglutinin by cobra venom is considered to be due to a phospholipase (Stone, 1946).

\section{Serological studies}

Absorption and centrifugation studies established the discrete nature of the Coxsackie A7 haemagglutinin. It seemed of interest, therefore, to determine whether there was any serological relationship between the haemagglutinin and the other serologically reactive materials present in extracts of Coxsackie A7 virusinfected tissue.

A haemagglutinin-free preparation was obtained by exhaustive absorption of an infected tissue extract with vaccinia-agglutinable fowl r.b.c. This preparation was then used to absorb Coxsackie A 7-immune mouse serum by mixing equal volumes of haemagglutinin-free preparation and immune serum and incubating the mixtures at $37^{\circ}$ for $2 \mathrm{hr}$ and then keeping at $4^{\circ}$ overnight. In order to increase the sensitivity of the test, the immune serum was diluted to 16 times the complement-fixing, haemagglutination inhibiting and neutralization titres before addition of the haemagglutinin-free preparation. After absorption, virus was removed by centrifugation at 40,000 rev./min. for $4 \mathrm{hr}$ in the no. 40 rotor of a Spinco Model L ultracentrifuge.

Table 2. Absorption of Coxsackie A7-immune mouse serum with a haemagglutinin-free extract of Coxsackie $A 7$ virus-infected suckling mouse tissue

\begin{tabular}{lrrr}
\multicolumn{1}{c}{ Antisera } & \multicolumn{3}{c}{ Serum titres* } \\
\cline { 2 - 4 } \multicolumn{1}{c}{ HI } & CF & VN \\
Unabsorbed serum & $\mathbf{5 1 2}$ & $\mathbf{1 2 8}$ & $\mathbf{2 0 4 8}$ \\
Absorbed serum & $\mathbf{1 2 8}$ & $<\mathbf{3 2}$ & $<\mathbf{5 1 2}$ \\
Normal serum & $<\mathbf{6 4}$ & $<\mathbf{3 2}$ & $<\mathbf{5 1 2}$
\end{tabular}

* HI, haemagglutination; CF, complement fixation; VN, virus neutralization.

Absorption of immune serum with the haemagglutinin-free preparation resulted in a marked decrease in complement-fixing and neutralization titres. This result was anticipated in view of the association of complement-fixing activity with the infective particle which was established by centrifugation studies. However, these reductions in titre were also accompanied by a significant specific decrease in 
haemagglutination-inhibition titre (Table 2). This result establishes that there is a serological relationship between the haemagglutinin and the other serologically reactive materials present in extracts of Coxsackie A7 virus-infected tissue.

\section{DISCUSSION}

Haemagglutinins specifically associated with enterovirus-infected tissues previously described may be classified in two groups. First, there are those in which haemagglutination is a property of the infective particle (Goldfield, Srihongse \& Fox, 1957). Under appropriate conditions, passage of such viruses may give rise to a mixed population of haemagglutinating and non-haemagglutinating virions (Johnon \& Lang, 1962). Absorption of extracts of tissues infected with such viruses with susceptible r.b.c. results in loss of haemagglutinating activity with concomitant complete or partial loss of infectivity.

The second group consists of those enteroviruses which infect tissues producing two types of haemagglutinin, one associated with the infective particle and the other non-infective haemagglutinin (Fabiyi, Engler \& Martin, 1964). Physical examination has shown that this second haemagglutinin is a particle of lower density than the infective particle and lacks the typical icosohedral symmetry of the virion. It is probable that the non-infective haemagglutinin is an 'incomplete' or 'coreless' form of the infective particle.

Absorption of Coxsackie A7 virus-infected tissue with vaccinia-agglutinable fowl r.b.c. removed the haemagglutinin without any detectable decrease in infectivity. Within the limits of sensitivity of the infectivity titration technique employed, these results show that the haemagglutinating activity is not associated with the infective particle. The results of density gradient centrifugation experiments suggest that the haemagglutinin and infective particle have the same density. It is unlikely, therefore, that the Coxsackie A7 haemagglutinin is an 'incomplete' virus particle. Indeed, differential centrifugation experiments suggest that the haemagglutinin is larger than the infective particle.

The Coxsackie A 7 haemagglutinin also differs from previously described enteroviral haemagglutinins in not agglutinating human group $\mathrm{O}$ cells. However, its inactivation by $p$-chloromercuribenzoic acid and subsequent reactivation by thiol compounds is a property typical of enteroviral haemagglutination (Buckland, 1960; Philipson \& Choppin, 1960).

Another paradoxical property of the Coxsackie A 7 haemagglutinin is its reactivity with vaccinia-agglutinable fowl r.b.c. Vaccinia haemagglutinin agglutinates only those fowl cells which are susceptible to agglutination by lipid suspensions (Burnet \& Stone, 1946); this property, together with the inactivation of vaccinia haemagglutinin by cobra venom and other preparations known to contain phospholipases, is a strong indication that the activity of the vaccinia haemagglutinin is associated with phospholipid (Stone, 1946). The physical and chemical studies described, however, suggest that the activity of the Coxsackie A 7 haemagglutinin is not associated with lipid but with protein. The differing chemical nature of the haemagglutinins suggests that the vaccinia and Coxsackie A7 haemagglutinins attach to susceptible fowl r.b.c. by different receptors. This hypothesis is at present under investigation. 
The significance of the production of haemagglutinins in Coxsackie A7 virusinfected suckling mouse tissue is still a matter for conjecture. Two main alternatives present themselves for the possible origin of the haemagglutinin: the haemagglutinin either is derived from normal host-cell constituents or else is synthesized de novo through the metabolic pathways of the virus-infected cells. Failure to detect similar haemagglutinins in similarly prepared extracts of uninfected tissues or in tissues infected with other Coxsackie viruses suggests that the active principle of haemagglutination is not a component of uninfected tissues. Since specific haemagglutinins have also been detected in Coxsackie A7 virus-infected tissue of a different rodent species, the adult cotton rat (Grist, 1962), production of haemagglutinins is not a phenomenon peculiar to suckling mouse tissue. Serological studies have established that the haemagglutinin is composed, in part at least, of virus-specific material. Further, it has been shown that antibodies specifically inhibiting haemagglutination cross-react with a haemagglutinin-free fraction of infected tissue extract. A common serological specificity must be shared, therefore, by both the haemagglutinin and other non-haemagglutinating virus-specific material. This suggests that the haemagglutinin carries two reactive sites only one of which is responsible for the haemagglutinating activity.

The authors wish to thank Mr T. Miller for his valuable technical assistance and Dr J. G. P. Hutchison for the cobra venom. This work was assisted by grants from the Scottish Hospitals Endowment Research Trust and the National Fund for Research into Poliomyelitis and other Crippling Diseases. One of us (J.D.W.) was Sir Maurice Bloch Research Fellow when this work was done.

\section{REFERENCES}

Briody, A. (1951). A 'unitarian' view of vaccinia haemagglutinin. Yale J. Biol. Med. 24, 1 .

BuckLAND, F. E. (1960). Inactivation of virus haemagglutinins by para-chloromercuribenzoic acid. Nature, Lond. $188,768$.

Buckland, F. E. \& Tyrnell, D. A. J. (1963). A comparative study of virus haemagglutinins. The stability of haemagglutinins and red cell receptors to certain chemical and physical treatments. J. gen. Microbiol. 32, 241.

Burnet, F. M. \& Stone, J. D. (1946). The haemagglutinins of vaccinia and ectromelia viruses. Aust. J. exp. Biol. med. Sci. 24, 1.

Chlap, Z. \& Lutynski, R. (1964). Experimental infection with coxsackie A7 virus. 1. Course of the infection and morphology of the lesions in white mice. Acta. med. pol., vars. 5, 255.

Chumakov, M. P., Voroshilova, M. K., Zhevandrova, V. I., Mironova, L. L., Izelis, F. G. \& Robinson, I. A. (1956). Isolation and study of immunologic type IV poliomyelitis virus. Probl. Virol. 1, 16.

Fabiyi, A., Engler, R. \& Martin, D. C. (1964). Physical properties of infectious unit, haemagglutinin and complement-fixing antigen of ECHO 19 virus. Arch. ges. Virusforsch. 14, 621 .

Goldfield, M., Srihongse, S. \& Fox, J. P. (1957). Haemagglutinins associated with certain enteric viruses. Proc. Soc. exp. Biol., N. Y. 96, 788.

GRIST, N. R. (1960). Isolation of Coxsackie A7 virus in Scotland. Lancet, i, 1054.

Grist, N. R. (1962). The pathogenicity and haemagglutinin of Coxsackie A7 virus. Fed. Proc. 21, 458.

Grist, N. R. \& Bell, E. J. (1964). Paralysis due to enteroviruses other than poliovirus. Eur. Ass. Poliomyelitis Allied Diseases, 9, 266. 
Grist, N. R. \& Roberts, G. B. S. (1962). Histological studies of Coxsackie A7 poliomyelitis in man and monkeys. J. Path. Bact. 84, 39.

Grist, N. R., Ross, C. A. C., BeLl, E. J. \& Stott, E. J. (1965). Diagnostic Methods in Clinical Virology. Oxford: Blackwell Scientific Publications Ltd. (in the Press).

Habel, K. \& Loomis, L. N. (1957). Coxsackie A7 virus and the Russian 'Poliovirus Type 4'. Proc. Soc. exp. Biol., N. Y. 95, 597.

Herberman, R. B. (1964). Studies on the nature of the haemolytic activity of tissue homogenates. Brit. J. exp. Path. 45, 560.

Johnson, K. M. \& LANG, D. J. (1962). Separation of haemagglutinating and non-haemagglutinating variants of Coxsackie A21 virus. Proc. Soc. exp. Biol., N. Y. 110, 653.

Philipson, L. \& Choppin, P. W. (1960). On the role of virus sulphydryl groups in the attachment of enteroviruses to erythrocytes. J. exp. Med. 112, 768.

Rossi, E., VAssella, F. \& Rentsch, M. (1964). Enterovirus vivants non-poliomyélitiques capables de produire des paralysies. Eur. Ass. Poliomyelitis and Allied Diseases, 9, 257.

STONE, J. D. (1946). Inactivation of vaccinia and ectromelia virus by lecithinase. Aust. $J$. exp. Biol. med. Sci. 24, 191.

Voroshinova, M. K. (1964). The problem of poliomyelitis-like diseases. Eur. Ass. Poliomyelitis and Allied Diseases, 9, 247.

Voroshilova, M. K. \& Chumakov, M. P. (1959). Poliomyelitis properties of AB-IVCoxsackie A7 group of viruses. Progr. med. Virol. 2, 106.

Youngner, J. S. \& Rubinstein, G. (1962). Separation and characterisation of haemagglutinins from chorioallantoic membranes of embryonated eggs infected with vaccinia virus. Virology, 16, 272. 